\title{
The Role of PCSK9 Inhibitors in Preventing Coronary Artery Disease
}

\section{Ryo Naito ${ }^{1}$ and Takatoshi Kasai ${ }^{2,3 *}$}

${ }^{1}$ Department of Cardiovascular Medicine, Juntendo University Urayasu Hospital, Japan

${ }^{2}$ Cardiovascular Respiratory Sleep Medicine, Juntendo University Graduate School of Medicine, Japan

${ }^{3}$ Department of Cardiovascular Medicine, Juntendo University School of Medicine, Japan

\section{Introduction}

Lipid-lowering therapy with statins has been established as effective treatment for preventing cardiovascular events. However, a lipid-lowering strategy is yet to be established for specific subsets of patients such as those with familial hypercholesterolemia or those who cannot tolerate statin therapy. The enzyme proprotein convertase subtilisin/kexin type 9 (PCSK9) binds to low-density lipoprotein (LDL) cholesterol receptors in the liver, causing receptor breakdown and the inability to eliminate LDL cholesterol from the blood. When PCSK9 is inhibited, LDL receptors maintain their function and the serum concentration of LDL cholesterol can be reduced. Several clinical studies have demonstrated that PCSK9 inhibitors reduce LDL cholesterol significantly when added to statin therapy $[1,2]$. However, the effect of PCSK9 inhibitors on preventing cardiovascular events has not been examined. Here, we reviewed and summarized current evidence regarding PCSK9 inhibitors.

Despite increasing preventive efforts, most individuals will develop cardiovascular disease (CVD), and this condition is still the most common cause of death worldwide $[3,4]$. Current CVD prevention strategies include comprehensive control of modifiable risk factors such as diabetes mellitus, hypertension, smoking, obesity, and dyslipidemia, as comprehensive risk management reduces the incidence of cardiovascular events4. Several large-scale clinical trials have demonstrated that lipid-lowering therapy with statin reduces the incidence of CVD events. Meta-analyses by the Cholesterol Treatment Trialists' collaboration reported that a $1 \mathrm{mmol} / \mathrm{L}$ reduction in LDL cholesterol levels lowered the incidence of CVD events by $21 \%$. This evidence resulted in revisions to the guidelines published by the American Heart Association/American College of Cardiology and European Society of Cardiology, and consequently, aggressive lipid-lowering therapy with strong statins is currently recommended to prevent CVD events $[5,6]$. In its guidelines for preventing atherosclerotic diseases, the Japanese Atherosclerosis Society set a target LDL cholesterol level depending on patients' backgrounds [7]. However, the percentage of patients in whom these target values are achieved is quite low [7-9]. Factors associated with this poor achievement of lipid control include insufficient doses of lipidlowering drugs, poor compliance, adverse effects of statins as well as familial hypercholesterolemia, which is resistant to any medical therapy, even aggressive lipid-lowering therapy.

Several clinical studies have demonstrated that PCSK9 inhibitors significantly reduce LDL cholesterol levels when added to statin therapy. To date, phase III clinical studies have been conducted for the first two PCSK9 inhibitors introduced, namely, evolocumab and alirocumab, which were approved by the U.S. Food and Drug Administration in 2015 for lowering LDL cholesterol levels in cases in which these levels could not be sufficiently reduced using statins or other drugs. These studies reported that PCSK9 inhibitors reduced LDL cholesterol levels by approximately $60 \%$ when added to statin therapy [10-14]. PCSK9 inhibitors reduce the levels of not only LDL cholesterol but also lipoprotein(a) ( $\operatorname{Lp}(\mathrm{a}))$, which is associated with progression of atherosclerotic diseases [15]. With regard to the effect

\section{Publication History:}

Received: March 17, 2016

Accepted: May 25, 2016

Published: May 27, 2016

\section{Keywords:}

Coronary artery disease, PCSK9 Inhibitors, L ow-density lipoprotein, Cardiovascular disease

of PCSK9 inhibitors on preventing cardiovascular events, limited data are available up until 2015. Both the Open-Label Study of LongTerm Evaluation against LDL Cholesterol (OSLER) trial [16] using evolocumab and the Long-term Safety and Tolerability of Alirocumab in High Cardiovascular Risk Patients with Hypercholesterolemia Not Adequately Controlled with Their Lipid Modifying Therapy (ODYSSEY LONG TERM) trial [17] using alirocumab demonstrated the cardiovascular protective effect of these drugs, although the primary endpoints in these trials were not cardiovascular events but merely a reduction in the LDL cholesterol levels and safety of the drugs.

\section{Osler}

The OSLER trial [16] was an open-label randomized trial conducted to examine the lipid-lowering and cardiovascular protective effects of evolocumab. A total of 4465 patients who had completed phase II or III studies of evolocumab were randomly assigned to receive evolocumab therapy ( $140 \mathrm{mg}$ every 2 weeks or $420 \mathrm{mg}$ monthly) plus standard therapy or standard therapy alone. During a median followup of 11.1 months, lipid profiles and safety were assessed in addition to cardiovascular events including death, myocardial infarction, unstable angina, coronary revascularization, stroke, transient ischemic attack, and heart failure. Evolocumab reduced LDL cholesterol levels by $61 \%$, non-HDL cholesterol levels by $52 \%$, apolipoprotein B levels by $47 \%$, Lp(a) levels by $26 \%$, and triglyceride levels by $13 \%$ compared to standard therapy alone. The reduction in the incidence of cardiovascular events at 1 year, which was a pre-specified exploratory outcome, was statistically significant in the evolocumab group $(0.95 \%$ vs. $2.18 \%$; hazard ratio, 0.47 ; $95 \%$ confidence interval, $0.28-0.78$; $\mathrm{P}=$ 0.003 ) (Table). The cardiovascular benefit was mainly derived from a reduction in coronary revascularization. The risk of adverse events was similar between the groups, except for neurocognitive events, which were more frequent in the evolocumab group than the standard therapy group ( $0.9 \%$ vs. $0.3 \%)$.

*Corresponding Author: Dr. Takatoshi Kasai, Department of Cardiovascular Medicine, Juntendo University School of Medicine, Bunkyo, Tokyo 113-0033, Japan; E-mail: takatoshi.kasai@gmail.com

Citation: Kasai T, Naito R (2016) The Role of PCSK9 Inhibitors in Preventing Coronary Artery Disease. Int J Clin Case Stud 2: 112. doi: https://doi. org/10.15344/2455-2356/2016/112

Copyright: () 2016 Kasai et al. This is an open-access article distributed under the terms of the Creative Commons Attribution License, which permits unrestricted use, distribution, and reproduction in any medium, provided the original author and source are credited. 
Citation: Kasai T, Naito R (2016) The Role of PCSK9 Inhibitors in Preventing Coronary Artery Disease. Int J Clin Case Stud 2: 112. doi: https:/doi. $\operatorname{org} / 10.15344 / 2455-2356 / 2016 / 112$

Page 2 of 3

\section{Odyssey Long Term Study}

ODYSSEY LONG TERM was a randomized double-blind controlled trial comparing alirocumab and placebo in patients at high risk for cardiovascular events who had LDL cholesterol levels of $70 \mathrm{mg} / \mathrm{L}$ or more and were on statins at the maximum tolerated dose. Alirocumab at $150 \mathrm{mg}$ every 2 weeks significantly improved the lipid profiles of these patients compared to the placebo (LDL cholesterol levels reduced by $61 \%$; $L p(a)$ levels, by $29 \%$; and triglyceride levels, by $17 \%$ ). In a post-hoc analysis that evaluated a pre-specified endpoint, the rate of major adverse cardiovascular events (death from coronary heart disease, non-fatal myocardial infarction, fatal or non-fatal ischemic stroke, and unstable angina requiring hospitalization) during a mean follow-up period of 80 weeks was lower in the alirocumab group than the placebo group ( $1.7 \%$ vs. $3.3 \%$; hazard ratio, $0.52 ; 95 \%$ confidence interval, 0.31-0.90; $\mathrm{P}=0.02$ ) (Table 1). However, the alirocumab group had a higher incidence of myalgia ( $5.4 \%$ vs. $2.9 \%, \mathrm{P}=0.006)$, while the rate of injection-site reactions and neurocognitive events did not statistically differ between the groups.

\section{Systematic Review And Meta-Analysis}

A systematic review and meta-analysis including 24 clinical trials reported that PCSK9 inhibitors reduced all-cause mortality and the incidence of myocardial infarction in individuals with hypercholesterolemia [18]. PCSK9 inhibitors showed a tendency to reduce the cardiovascular mortality rate (Table 1 ).

\section{Future Perspectives}

Currently, two large-scale clinical trials examining the effect of PCSK9 inhibitors on reducing cardiovascular events are underway. The first, entitled "Further Cardiovascular Outcomes Research with PCSK9 inhibition in Subjects with Elevated Risk (FOURIER)," includes 22500 individuals using evolocumab and is expected to be published in 2017. The other is ODYSSEY OUTCOMES, which examined the effectiveness of alirocumab on preventing cardiovascular events in 18000 individuals. If these trials show that PCSK9 inhibitors are successful in preventing cardiovascular events, it will be of great interest to understand the underlying mechanisms, how these drugs marry into the notion of "the lower, the better" regarding LDL cholesterol levels, and other mechanisms of action that are independent of the LDL cholesterol-lowering effects of these drugs.

\section{Conclusions}

PCSK9 inhibitors may be effective for preventing cardiovascular events. Ongoing large-scale clinical trials should reveal whether or not these drugs are effective in improving cardiovascular outcomes.

\section{References}

1. Roth EM, McKenney JM, Hanotin C, Asset G, Stein EA (2012) Atorvastatin with or without an antibody to PCSK9 in primary hypercholesterolemia. N Engl J Med 367: 1891-1900

2. Stein EA, Gipe D, Bergeron J, Gaudet D, Weiss R, et al. (2012) Effect of a monoclonal antibody to PCSK9, REGN727/SAR236553, to reduce low-density lipoprotein cholesterol in patients with heterozygous familial hypercholesterolaemia on stable statin dose with or without ezetimibe therapy: a phase 2 randomised controlled trial. Lancet 380: 29-36.

3. Iso $H$ (2011) Lifestyle and cardiovascular disease in Japan. J Atheroscler Thromb 18: 83-88.

4. Heart Care Network Groups (2009) Current trends in lifestyle-related disease management by general practitioners: a report from the "Heart Care Network" groups. J Atheroscler Thromb 16: 799-806

5. ESC/EAS Guidelines for the management of dyslipidaemias: the Task Force for the management of dyslipidaemias of the European Society of Cardiology (ESC) and the European Atherosclerosis Society (EAS). European Association for Cardiovascular Prevention \& Rehabilitation, Reiner Z, Catapano AL, De Backer G, Graham I, Taskinen MR, et al. (2011) ESC Committee for Practice Guidelines (CPG) 2008-2010 and 2010-2012 Committees. Eur Heart J 32: 1769.

6. 2013 ACC/AHA guideline on the treatment of blood cholesterol to reduce atherosclerotic cardiovascular risk in adults: a report of the American College of Cardiology/American Heart Association Task Force on Practice Guidelines. Stone NJ, Robinson JG, Lichtenstein AH, Bairey Merz CN, Blum CB, et al. (2014) American College of Cardiology/American Heart Association Task Force on Practice Guidelines. Circulation. 129: S1.

7. Teramoto T, Sasaki J, Ishibashi S, Birou S, Daida H, et al. (2013) Japan Atherosclerosis Society. Executive summary of the Japan Atherosclerosis Society (JAS) guidelines for the diagnosis and prevention of atherosclerotic cardiovascular diseases in Japan -2012 version. J Atheroscler Thromb 20: 517.

\begin{tabular}{|c|c|c|c|c|c|c|c|c|}
\hline Trial & Patients, $\mathbf{n}$ & Disease & Intervention & $\begin{array}{l}\text { Follow-up } \\
\text { period }\end{array}$ & Cardiovascular events & $\begin{array}{l}\text { Hazard } \\
\text { ratio }\end{array}$ & $95 \% \mathrm{CI}$ & $\mathbf{P}$ \\
\hline OSLER $^{16}$ & 4465 & $\begin{array}{l}\text { statin-intolerant, } \\
\text { heterozygous familial } \\
\text { hypercholesterolemia } \\
\text { or inadequate control } \\
\text { of LDL cholesterol } \\
\text { levels with statins }\end{array}$ & $\begin{array}{l}\text { evolocumab } \\
420 \text { mg once a } \\
\text { month or } \\
140 \text { mg every } \\
2 \text { weeks }\end{array}$ & 11.1 months & $\begin{array}{l}\text { death, myocardial } \\
\text { infarction, unstable angina, } \\
\text { coronary revascularization, } \\
\text { stroke, transient ischemic } \\
\text { attack, or heart failure }\end{array}$ & 0.47 & $0.28-0.78$ & 0.003 \\
\hline \multirow[t]{2}{*}{$\begin{array}{l}\text { ODYSSEY } \\
\text { LONG TERM17 }\end{array}$} & 2341 & $\begin{array}{l}\text { heterozygous familial } \\
\text { hypercholesterolemia, } \\
\text { coronary heart disease, } \\
\text { or coronary heart } \\
\text { disease equivalent with } \\
\text { LDL cholesterol levels } \\
\geq 70 \mathrm{mg} / \mathrm{dL}\end{array}$ & $\begin{array}{l}\text { alirocumab } \\
150 \text { mg every } \\
2 \text { weeks }\end{array}$ & 80 weeks & $\begin{array}{l}\text { death from coronary } \\
\text { heart disease, non-fatal } \\
\text { myocardial infarction, fatal } \\
\text { or non-fatal ischemic stroke, } \\
\text { or unstable angina requiring } \\
\text { hospitalization }\end{array}$ & 0.52 & $0.31-0.90$ & 0.02 \\
\hline & Patients, n & Disease & Intervention & & Cardiovascular events & $\begin{array}{l}\text { Odds } \\
\text { ratio }\end{array}$ & $95 \% \mathrm{CI}$ & $\mathbf{P}$ \\
\hline Meta-analysis $^{18}$ & 10159 & $\begin{array}{l}\text { adult } \\
\text { hypercholesterolemia }\end{array}$ & $\begin{array}{l}\text { evolocumab or } \\
\text { alirocumab }\end{array}$ & & $\begin{array}{l}\text { All-cause mortality } \\
\text { Cardiovascular mortality } \\
\text { Myocardial infarction }\end{array}$ & $\begin{array}{l}0.45 \\
0.5 \\
0.49\end{array}$ & $\begin{array}{l}0.23-0.86 \\
0.23-1.10 \\
0.26-0.93\end{array}$ & $\begin{array}{l}0.015 \\
0.084 \\
0.03\end{array}$ \\
\hline
\end{tabular}

Table 1: PCSK9 inhibitors showed a tendency to reduce the cardiovascular mortality rate. 
Citation: Kasai T, Naito R (2016) The Role of PCSK9 Inhibitors in Preventing Coronary Artery Disease. Int J Clin Case Stud 2: 112. doi: https://doi. org/10.15344/2455-2356/2016/112

Page 3 of 3

8. Kurihara Y (2007) A large-scale, prospective post-marketing surveillance of pitavastatin (LIVALOßtablet) Drug use investigation. Jpn Pharmacol Ther 35: $9-40$

9. Pijlman AH, Huijgen R, Verhagen SN, Imholz BP, Liem AH, et al. (2010) Evaluation of cholesterol lowering treatment of patients with familia hypercholesterolemia: a large cross-sectional study in The Netherlands. Atherosclerosis 209: 189-194.

10. Stroes E, Colquhoun D, Sullivan D, Civeira F, Rosenson RS, et al.; GAUSS-2 Investigators (2014) Anti-PCSK9 antibody effectively lowers cholesterol in patients with statin intolerance: the GAUSS-2 randomized, placebo-controlled phase 3 clinical trial of evolocumab. J Am Coll Cardiol 63: 2541-2548.

11. Raal FJ, Honarpour N, Blom DJ, Hovingh GK, Xu F, et al.; TESLA Investigators (2015) Inhibition of PCSK9 with evolocumab in homozygous familial hypercholesterolaemia (TESLA Part B): a randomised, doubleblind, placebo-controlled trial. Lancet. 385: 341-350.

12. Robinson JG, Nedergaard BS, Rogers WJ, Fialkow J, Neutel JM, et al. LAPLACE-2 Investigators (2014) Effect of evolocumab or ezetimibe added to moderate- or high-intensity statin therapy on LDL-C lowering in patients with hypercholesterolemia: the LAPLACE-2 randomized clinical trial. JAMA. 311: 1870-1182.

13. Blom DJ, Hala T, Bolognese M, Lillestol MJ, Toth PD, et al.; DESCARTES Investigators (2014) A 52-week placebo-controlled trial of evolocumab in hyperlipidemia. New Engl J Med 370: 1809-1819.

14. McKenney JM, Koren MJ, Kereiakes DJ, Hanotin C, Ferrand AC, et al. (2012) Safety and efficacy of a monoclonal antibody to proprotein convertase subtilisin/kexin type 9 serine protease, SAR236553/REGN727, in patients with primary hypercholesterolemia receiving ongoing stable atorvastatin therapy. J Am Coll Cardiol. 59: 2344-2353.

15. Konishi H, Miyauchi K, Kasai T, Tsuboi S, Ogita M, et al. (2015) Impact of lipoprotein(a) as residual risk on long-term outcomes in patients after percutaneous coronary intervention. Am J Cardiol. 115: 157-160.

16. Sabatine MS, Giugliano RP, Wiviott SD, Raal FJ, Blom DJ, et al. (2015) Open-Label Study of Long-Term Evaluation against LDL Cholesterol (OSLER) Investigators. Efficacy and safety of evolocumab in reducing lipids and cardiovascular events. N Engl J Med 372: 1500.

17. Robinson JG, Farnier M, Krempf M, Bergeron J, Luc G, et al. (2015) Efficacy and safety of alirocumab in reducing lipids and cardiovascular events. N Engl J Med 372: 1489-1499.

18. Navarese EP, Kolodziejczak M, Schulze V, Gurbel PA, Tantry U, et al (2015) Effects of Proprotein Convertase Subtilisin/Kexin Type 9 Antibodies in Adults With Hypercholesterolemia: A Systematic Review and Metaanalysis. Ann Intern Med 163: 40-51. 